\title{
THE USE AND SYMBOLISM OF ANIMALS IN THE WONDERFUL WIZARD OF OZ
}

\author{
Taymaa Hussein Kheirbek, Roza Awat Ezzat \\ Department of English language, College of Education, \\ Charmo University, Alsulaymania, Kurdistan Region, Iraq \\ E-mail: taymaa.hussein@charmouniversity.org
}

Received: 07 October 2020

Accepted: 07 December 2020

\begin{abstract}
This paper is the result of a qualitative research that follows an animalbased interpretative theory. It sheds the light on the use and symbolism of animal characters in The Wonderful Wizard of Oz written by L. Frank Baum and published in 1900. It seems to be a modern fairy tale with an American setting and charming fantasy characters. It is an immensely popular text among children and adults, so it is considered a classic of children's literature. It also attempts to answer why and how Baum used animals; whether for their qualities or for the sake of creating characters opposite to their symbolism. Therefore, the role and function of animal characters are extensively discussed. The findings show how L. Frank Baum presents a distinguished world from a non-human perspective and at the same time he teaches morality, religion, and accepting diversity in nature in an exciting narrative full of adventures. These animal characters can serve as a symbolic role models for young readers.
\end{abstract}

Keywords: symbolism, children's literature, narrative, fantasy.

\section{Introduction}

When The Wonderful Wizard of Oz was first published, it caught the readers' and the critics' attention alike. According to the New York Times, the story's comic sense and philosophy are the reasons behind making children enjoy the story. In addition to that, the atmosphere gives an optimistic feeling. Patric Hearn believes that "The Scarecrow, the Tin Woodman, and the Cowardly Lion have entered the collective consciousness of childhood" (The Wonderful Wizard of Oz, 2020), moreover, he compared Baum to Twain and Dicken's rare talent of creating unforgettable characters. Though most of the characters are not humans, the way Baum created them for questing human attributes is unique. Philip Jose Farmer remarks that "all the characters possessed the qualities which they desired yet they did not realize it, they are "the stuff of which classics are made" (Ibid). James Thurber also stated that Baum took the experiment of making unrealistic animals to see if he could make animated creatures look real (Ibid). Many critics think that not only children like the book, but adults appreciate it too. Farmer explained the role of fantasy, which leads to escaping from adulthood into childhood again.

Amanda Spake adds that "One hundred years after its publication, it remains the most significant children's book in American history: No other fantasy is more beloved, hated, cited, imitated, interpreted, adapted, or marketed" (Ibid). Some scholars believe it is an allegorical work written to describe America's circumstances at that time. While Baum 
argued that his only intention was entertainment, so he created unreal animals such as Kalidahs (Ibid).

L. Frank Baum dedicated The Wonderful Wizard of $\mathrm{Oz}$ to children who aimed for pure entertainment. As he stated, "modernized fairy tale, in which the wonderment and joy are retained and the heart-aches and nightmares are left out" (Holleran, 2014). An essential part of the text's magic is its fabulous animal characters. They play a significant role in the plot since they participate in most of the major events. The use of animals in literature is very old, but Baum succeeded in modernizing it by presenting various characters with different roles and uses.

Despite the fact that The Wonderful Wizard of $\mathrm{Oz}$ has been considered significant for literary analysis, the special techniques that Baum used in the utilization of animals has not been studied. This paper studies the animal characters in relation to their use and symbolism. Each animal is discussed in details with mentioning the purpose behind using it in the text.

\section{Literature Review}

Animals play significant roles in literature. The ancient storytellers used animals for teaching morality, such as Aesop's Fables. In the beginning, writers used domestic animals in their writing such as (hens, horses, dogs, lambs, donkeys, ducks, cows, etc.). Then, wild animals were used like (lion, tiger, beast, pigs, bears, and fox) (Carpenter and Prichard, 1999: 10). Black Beauty by Anne Sewell used a horse as a protagonist and through this character she explained humans' attitude and cruelty towards animals. Charles Dickens used a dog to represent the owner's violent and criminal side in Oliver Twist. The Call of the wild in 1903 by Jack London presented the character of Buck to show human qualities, thoughts, and behaviors. Poets like Alexander Pope demonstrated great compassion for animals in his writing. In one of his famous poems Essay of Man, he claimed that animals share the feeling of joy, love, pleasure, and pride with human beings (Prior, 2011). William Blake's The Lamb, Hans Christian Andersen's The Ugly Duckling, and Oscar Wilde's The Happy Prince are other significant examples of using animal characters. For some authors, animals must retain at least some of their natural behavior, thereby they tend to create a story that is unique to that particular animal" (Dunn, 2011:2-4).

Another important reason for authors to choose animals in their writing is that most children prefer reading books that contain animals. Hence, animals are more interesting than humans which makes children find it easier to connect to them. Carolyn L. Burke and Jobby G. Copenhaver point out that "those animals add an emotional distance that makes them ideal characters for addressing difficult subjects like death, bullying, race, and social class, respect differences, and making the right decision when the story-telling is powerful or painful" (Azmiry, 2014: 27). In addition to that fantasy creates an imaginative world. Animals also allow developing a great variety of characters in a short book with few words. Most of the children do not see animals as mere creatures, they believe that animals have human characteristics (Markowsky, 1975: 461).

\section{Research Method}

The paper is a qualitative research about the use and symbolism of animals in The Wonderful Wizard of Oz. It is an animal-based research in which all the animal characters are studied. The study also provides the relevant analysis of animals and their symbolism with evidence of the causes behind their uses. The animals are mentioned according to their 
appearance in the text. Certain differences are taken into consideration and thoroughly discussed such as being talking or nontalking, male or female, and wild or domesticated animals. An extensive historical background of the use of each animal in literature is also given. The results show how these animal characters can serve as a symbolic role models for young readers.

\section{Results and Discussion}

The novel The Wonderful Wizard of Oz was written by Lyman Frank Baum in 1900. He took ideas from his real-life to create some characters and elements in the novel like The Tin Tinman and the yellow road. Baum was a heart patient, so let the Tin Tinman search for a heart. Moreover, he took the idea of a yellow path when he was at the Peekskill Military Academy as hope for soldiers returning home. Frank got the image of creating scarecrows through a dream that he had and said: "every time I had a nightmare about that screw chased me but collapsed into a pile of straw before catching me". Baum caught the idea of using animals in his writing through the zoology activities in his newspaper The Local News (Rogers, 2002: 1-5).

The Wonderful Wizard of Oz became the best-selling book of the 19th century. The popularity of the book made Frank write 12 other books as a series. The illustration and Baum's imagination created the success of the novel. Michael Patrick Hearn stated that Baum was interested in children, and he was able to recognize what children want (Abrams, 2010, 67-71). Indeed, All the characters in the novel have pictures that attracted readers, entertained them, and each design described action as Baum believed in performance. Those pictures that twist with the conversations are more innovative and gave them a distinctive shape. For instance, in the beginning of the first chapter Dorothy appears leaning on the capital letter with a picture (Abrams, 2012: 67-71). The researchers study the animals in The Wonderful Wizard of $\mathrm{Oz}$ according to their appearance in the novel. At the beginning of the story, Toto appeared then the Old Crow and The Cowardly lion. After them, Kalidahs, the Stork, the Wildcat, the Queen of the Field Mice, and the Winged monkeys emerged in the novel.

\section{Toto}

Baum, in The Wonderful Wizard of $\mathrm{Oz}$ includes numerous figures of speech, and to convey his message he simply uses animals. Authors prefer dogs rather than any other animals. According to the Legend of the Tehuelche Indians, god created a dog immediately after he created Adam and Eve to keep them company (the Mythical Zoo). Dogs are "man's best friend" the faithful, loving companion (Dunn, 2011: 9).

Toto is a dog in the novel, during the 19th century Toto was a famous name for dogs. He is the first animal which appears at the beginning of chapter one, Baum describes him as:

A little black dog, with long silky hair and small black eyes that twinkled merrily on either side of his funny, wee nose. Toto played all day long, and Dorothy played with him, and loved him dearly (Baum, 1900:3).

This shows that Toto differs from others who have lived in Kansas since he was black, not grey, and played with his mistress all day, not similar to Aunt Em or Uncle Henry who were busy. Baum used Toto as a tool to symbolize that maximum times one adores something or a person who causes difficulties unintentionally, still produces happiness that one cannot neglect. Toto is responsible for Dorothy's trip to Oz City and her failure to return 
to Kansas. During the cyclone, Dorothy was looking for Toto where she falls asleep and the cyclone takes her to a new place. Plus, when she is about to return Toto is missing and Dorothy did not wish to leave her dog so the balloons rose into the air and left them behind.

Dorothy considered Toto her dog, although Baum designed Toto as a "mongrel" dog (Hearn, 2000: 21). This explains that whatever gives pleasure man will objectify it. Furthermore, she considers him part of her little family and is always concerned about him throughout their adventure. Dorothy is an orphan girl, who finds a mother in Aunt Em and at the same time, she has a motherhood feeling for Toto. Thus, they have a parallel relationship.

Baum wanted to provide a moral lesson through Toto's role which is animals are part of our universe. When the Cowardly Lion wants to hurt him instantly she slaps him and says "Don't you dare to bite Toto! You ought to be ashamed of yourself, a big beast like you, to bite a poor little dog!" (Baum, 1900: 42). This clarifies that Baum wanted to advise children to respect every part of nature whether it is a living or non-living creature. Furthermore, Toto pursues the mice and finds no harm in it. This shows that whoever has power abuses others. When the Cowardly Lion asks whether Toto "Is he made of tin, or stuffed?" (Baum, $1900,43)$. Next, Dorothy responds " Neither. He's a- a- a- meat dog" (Baum, 1900, 43). This proves that Toto represents a state of animals. According to Hearn, Baum distinguished Toto from the other fanciful characters, by using the word "meat" (Hearn, 2000, 110).

Toto is the only character in the novel who does not speak. The man in the house talked to Toto, but he only wagged his tail as he could not say: I am unable to talk. Plus, when the Wicked Witch of West caught them, Dorothy was sad and sometimes she cried for hours, Toto was sad but could not describe it. These examples show he is the only animal from the real world. Aleksandr Volkov describes Toto as "dumb" since all the animals speak, and he chooses to stay silent. In another book in the series of $\mathrm{Oz}$, readers discover that he can talk, and according to Aleksandr "the clever and the loyal Toto ought also to speak" (Hearn, 2000, 168).

As long as Dorothy is with him, Toto does not care where he is, which shows he is a trustworthy comrade. He exposes the Great $\mathrm{Oz}$ behind the curtains. The Wizard of $\mathrm{Oz}$ is an ordinary man, who tries to deceive them. According to Littlefield Toto represents Prohibitionists since Baum has played with his name "teetotaler" political associates of Populists.

Baum established Toto as a loyal friend who shows unconditional love for his owner. The purpose behind using a dog is that dogs are regarded as domestic and faithful animals and decent fellows that protect its owner. Baum required a creature that sheltered and entertained his leading character. For instance, when the Wicked Witch of West struck Toto with her umbrella, he quickly grips her leg because he knew that by striking him; she attempts to damage Dorothy (Gutierrez, 2014).

\section{Old Crow}

The crow is considered a spiritual animal. Which symbolizes Intelligence, Prophetic, Love, Mindfulness, Honesty, and Sincerity. Scientists believe that he is a genius animal that warns other animals about hunters (Biraban, 2019). Baum used the Old Crow as those people who interfere in other's life and criticize them. The Old Crow comforted the Scarecrow when he is sad for being an inadequate Scarecrow. 
If you only had brains in your head you would be as good a man as any of them, and a better man than some of them. Brains are the only things worth having in this world, no matter whether one is a crow or a man (Baum, 1900: 30).

The Old Crow is intelligent and wise. He talks like a philosopher, and he encourages Scarecrows to travel for finding a brain. The Old Crow represents the people who support others to reach their goals.

\section{The Cowardly Lion}

Authors habitually use lions not only as powerful beasts, but noble and glorious ones. As lions own limitless strength, they petrify other creatures. Lions are popular for royalty, bravery, and stateliness. The Cowardly Lion is the third character to join Dorothy and her companion. He seeks courage, yet all his action describes bravery. According to him, the reason behind his roar is to show how superior and powerful he is. He does not realize that courage means acting in the face of fear, which he performs that regularly. The cowardly lion believes due to his title "The King of Beasts" he is embarrassed about his cowardice. After he takes the liquid produced by $\mathrm{Oz}$, the cowardly lion enjoys his power and performs it without pondering it.

The Cowardly Lion appears at the beginning of Chapter 6. He could not obtain an impression although he roared noisily. After the Cowardly Lion attempts to bite Toto, he gets a slap by Dorothy and words that hurt Lion's reputation and emotion seriously. It is not the first time that writers consume lions for attacking but, unlike others, Baum tries to manipulate the reader's preconceptions. For example, when Dorothy angrily mocks The Cowardly Lion by declaring "You are nothing but a big coward" (Baum, 1900: 43), Baum proves that no matter how large a person is one requires courage and strength to justify actions. Baum uses "big Coward" for the lion which is an unusual way to describe this creature. According to Denslow, the idea behind choosing a coward title to a lion is to occupy elements of entertainment as a gesture to handle both wild and domestic animals. Plus, Baum demonstrates that the lion is as innocent as a house pet so no need to be terrified. One might look at Denslow's illustration of The Cowardly Lion and notice his tail between his legs this shows his cowardice (Hearn, 2000: 108).

The Coward Lion's conversation with Dorothy Proves that he also makes fun of himself "No one would think of biting such a little thing except a coward like me," (Baum, 1900, 43). This indicates he is ashamed of himself. When Dorothy asks him, what makes him a coward, he replies "It's a mystery" (Baum, 1900, 44) it clears that he is upset because of society especially his cultural name, and then he says: "I learned that if I roared very loudly every living thing was frightened and got out of my way" (Baum, 1900, 44). This explains the nature of imitation as people perform it without assuming it. Moreover, few people believe that by increasing voice one can achieve his/ her goal like the Cowardly Lion's state when he prepares meeting $\mathrm{Oz}$ "If he is a beast when I go to see him, I shall roar my loudest, and so frighten him that he will grant all I ask." (Baum, 1900: 93). Another interpretation of this character, according to Littlefield, is that The Cowardly Lion represents William Jennings Bryan because of his cowardice and roar was the influential director, in the Populist Movement (Liebhold, 2016).

Baum used irony to describe self-sufficiency; the Cowardly Lion considers himself a coward, but his actions contradict his statements like when he desires to kill a deer for Dorothy. The first opportunity that proves the Cowardly lion's courage is when he helps 
them crossing a ditch. He proves Ernest Hemingway's proverb that "courage is grace under pressure" (Hearn, 2000: 124). This reveals the hard work behind Cowardly Lion's attempts to justify his power. He is a marvellous comrade that sacrifices his life to his companions. One can say, Baum, explains the significance of friendship through this "Stand close behind me, and I will fight them as long as I am alive." (Baum, 1900: 53).

The Cowardly Lion cares for his reputation, hence he goes to meet the Great $\mathrm{Oz}$ and says "I am a Cowardly Lion, afraid of everything. I came to you to beg that you give me courage, so that in reality I may become the King of Beasts, as men call me." (Baum, 1900: 94). This indicates he cares for his reputation. Finally, after he swallows the portion, the Cowardly Lion gets an opportunity to demonstrate himself by killing a giant evil spider-like monster which was the size of an elephant and threatened the animals in the forest. Consequently, animals respected and considered him as a "King of Beasts."

The Cowardly Lion represents the confidence and courage in every man's heart. Baum uses a lion ironically to draw the reader's attention to the point of respect and calmness, also for protection and indicating limitless power.

\section{Kalidahs}

Kalidahs are mighty and ferocious beasts with figures the same as bears and heads like tigers. According to the Cowardly Lion, they have large and sharp claws that could cut him into two pieces simply. While Dorothy and her comrades continuing their adventure, two Kalidahs try to attack them. The Cowardly Lion succeeds in saving them by giving a loud and terrible roar that stops them for a short time. After Kalidahs know that they are bigger and more in number than the lion, they chase them again. Luckily, they escape because of the Tin Woodman who chops the tree so they can cross over the cliff.

Hearn believes that the name Kalidahs comes from "Kaleidoscope"; a kind of children doll that creates patterns from patterns shapes and mirrors. Another opinion is that Kalidahs comes from the Greek "Kaleidoscope" which means "beautiful form." (Fain, 22). Reilly \& Britton assume that Kalidahs appear in other series of $\mathrm{Oz}$, while Baum declared that "The Kalidahs do not appear in any of my books except The Wizard and not much about them there." (Hearn, 2000: 125). Baum combined two of the mightiest animals, bear and tiger, to form Kalidahs that shows both of animals' strength.

Kalidahs represent the difficulties that one gets rid of during their journey towards success and achievements. Baum used Kalidahs to provide the pleasure of something creative and modern to the children, also creating an outstanding world of fantasy far away from harshness or any blood.

\section{The Stork}

The Stork is among the animals that helps Dorothy and her friends in their adventure. According to Hearn, the stork was part of most of Baum's works as he was a feminist so he used the Stork as the first female to help them (Hearn, 2000: 137). Stork represents new life or beginning. Etymology, the stork is a Greek word that means "Mother love" (Bostwick, 2019). Baum used Stork for two fundamental reasons; first, to wish good luck to Dorothy and her friends, especially the Scarecrow since she is his savior and gives him new life, secondly, to show the power of women. When Dorothy informs her that Scarecrow is held in the river, she says "If he wasn't so big and heavy I would get him for you" (Baum, 1900: 60).

This proves that Baum advocated for women's equality and rights. He presents women as physically different from men, but they have the right to live and get the opportunity like 
males. Women in the 19th century were staying at home taking care of their children. However, some of them chose to work outsides too which presented in the character of the Stork "I always like to help anyone in trouble. But I must go now, for my babies are waiting in the nest for me" (Baum, 1900: 61) she portrays women empowerment and equality.

\section{The Wildcat}

The Wildcat is the creature that chases the Queen of the Field. Baum describes him as "A yellow Wildcat, its ears were lying close to its head and its mouth was wide open, showing two rows of ugly teeth, while its red eyes glowed like balls of fire." (Baum, 1900, 65). This shows that he is a savage beast and loves to chase innocent animals. After observing this, The Tin Woodman feels sad, so he "Raised his axe, and as the Wildcat run by, he gave it a quick blow that cut the beast's head clean off from its body, and it rolled over at his feet in two pieces." (Baum, 1900: 65).

Even though that The Wonderful Wizard of $\mathrm{Oz}$ is a child book, Baum used some violent words "Cut the beast's head clean off from its body." (Baum, 1900, 65). Modern critics of Juvenile literature believe that Children's books should not contain any of the violent elements. Baum created the Wildcat to show the contradiction of the Tin Woodman. He said: "The Tin Woodman was a peaceful man, but when occasion required he could fight as fiercely as a Roman gladiator" (Hearn, 2000: 149). The Wildcat symbolizes the injustice one observes or performs.

\section{Queen of the Field Mice}

Mice are familiar in literature. They are considered divine creatures, even in some countries they worship them. When Dorothy and her friends travel to Oz City, they come across "The Deadly Poppy Field" which causes Dorothy, Toto, and The Cowardly Lion to sleep. The Scarecrow and the Tin Woodman do not fall asleep as they do not have blood. They identify a wildcat trying to chase a little grey field mouse. When The Tin Woodman releases the mouse, he realizes that she is the queen of the field mice.

Baum was a supporter of women's rights and equality, so he created a charismatic girl like The Queen of the Field Mice. Since he was a religious man, he deployed a holy animal for two reasons; first, Baum used the Mice as an angel for Dorothy and her Ozian friend's savior. The Queen tells her people that Tin Woodman rescued her, and he must be awarded "So hereafter you must all serve him, and obey his slightest wish." (Baum, 1900: 66). Secondly, he wanted to show the quality of each character; Lion's cowardice, The Scarecrow's intelligence, and The Tin Woodman's emotion. For example, when they do not know how to go back to Emerald City, they call the Queen of the Field Mice "Suppose we call the Field Mice, they could probably tell us the way to Emerald City" (Baum, 1900: 72). When a big Lion is saved by a small Mouse, this shows that although The Queen knows that maybe she would be eaten by the Cowardly Lion, she saved his life from the deadly flowers.

Hearn believes that Baum investigated a similar theme as "The Wonderful Pump" where the poor woman saves a beetle who is the King of all the insects who decides to reward her for her kindness. The Queen rewards Dorothy and her friends for their contribution to saving her life. She says: "If you ever need me, come out into the field and call and we shall hear you and come to your assistance. Goodbye!" (Baum, 1900, 70). According to David L. Green, a member of $\mathrm{Oz}$ Club, he relates this event to Androcles and The Lion, in which favor repaid 
by another. The Queen of the Field Mice represents the spirit in one's life that encourage and support whenever necessary (Hearn, 2000: 149).

\section{The Winged Monkeys}

Monkeys are the most used animals in literature. During the 16th century, the word "Monkey" was added to the language, before that time, the term "apes" applied to indicate it. Monkeys are religious creatures, especially in India and China furthermore in many mythologies. Apes and monkeys are regarded as alternative human beings (Sax, 2001: 7). Winged Monkeys are those animals that help the Wicked Witch of West to catch the Cowardly Lion, Dorothy, and Toto, moreover, destroy the Tin Woodman and the Scarecrow. After Dorothy melts the Wicked Witch of West, Winged Monkeys help Dorothy and her friends.

The Winged Monkeys are the slaves of the Golden cap, whoever has the cap has to obey his/ her three wishes. When the Wicked Witch orders them to destroy Dorothy and her comrades, they stated, "Your commands shall be obeyed." Hearn believes that Baum used "the modernized equivalent of the stereotyped genies of the Arabian Nights" (Hearn, 2000: 210). After melting the Wicked Witch, Dorothy and her companion use the power of Golden Cap to transfer them to the Emerald City.

Monkeys signify pleasure, although the Winged Monkeys are the slave of the Golden Cap, yet their personality stays the same "but if you are going to call the Winged Monkeys we must run away, for they are full of mischief and think great fun to plague us." (Baum, 1900: 120). According to Hearn, Baum created animal fairies since the Winged Monkeys have wings; they can talk also they are similar to the Indian Monkey God "Hanuman" he also had wings (Sax,2001, 8). Dorothy asks the Winged monkeys "Why do you have to obey the charm of the Golden Cap?" (Baum, 1900: 122) They reply:

Once, we were a free people, living happily in the great forest, flying from tree to tree, eating nuts and fruit, and doing just as we pleased without calling anybody master. Perhaps some of us were rather too full of mischief at times, flying down to pull the tails of the animals that had no wings, chasing birds, and throwing nuts at the people who walked in the forest. But we were careless and happy and full of fun, and enjoyed every minute of the day. This was many years ago, long before $\mathrm{Oz}$ came out of the clouds to rule over this land (Baum, 1900: 122).

One day the Winged Monkey's Grandfather and her friends chase the princess husband 's Quelala by carrying him in their arms and drop him in the water. This made the princess Gayelette angry, and she decides to make them the slaves of the Golden Cap. One may observe the Winged monkeys as Native Americans as some of Baum's early writings about Native Americans are similar to Winged Monkeys' descriptions. The Good Witch Glinda demand The Golden Cap to return Dorothy to Kansas City, then she grants freedom to the Winged Monkeys.

\section{Conclusion}

Animals play an essential part in literature, particularly children's literature. Writers prefer using animals because they do not apply any political agenda or indication of racism. In addition to that, they create a comfortable bond with children, since they send hopeful messages about humanity, morality, good behaviour, kindness, and respect. Animal stories enable children to learn powerful lessons, which can be dramatic, but are not harmful. 
Many critics consider The Wonderful Wizard of Oz far superior to the other children's books, since Baum succeeded in creating a wonder without horror. Presenting fantasy in a moral lesson frame enabled him in making it one of the most famous classics in children's literature. Through animal characters, the text teaches children that instead of avoiding worries, one can face them. As a result, reading about these characters enables children to form their own of values.

\section{References}

Abrams, D. (2010). L. Frank Baum. New York: Chelsea House.

Azmiry, N. (2014). Animals and their Functions in Children's Literature Since 1900. Bangladeshi: university of Liberal Arts. www.academia.edu/11220842/ Animals_and_Their_Functions_in_Childrens_Literature_Since_1900

Baum, L. (1900). The Wonderful Wizard of Oz. Chicago: Hill Company.

Biraban, I. (2019). Crow Animal Totem Symbolism \& Meanings | Sunsigns.Org. Sun Signs. https://www.sunsigns.org/crow-animal-totem-symbolism-meanings/

Bostwick, L. (2019). Stork Animal Totem Symbolism \& Meanings | Sunsigns.Org. Sun Signs. https://www.sunsigns.org/stork-animal-totem-symbolism-meanings/

Carpenter, H. and Prichard, M. (1999). The Oxford Companion to Children's Literature. Oxford: Oxford University Press.

Dunn, E. (2011). Talking Animals: A Literature Review of Anthropomorphism in Children's Books. UNC: Carolina Digital Repository. http://cdr.lib.unc.edu/indexablecontent/ uuid:627a29d7-25f1-4481-9363-72e74c0c4b3f.

Fain, R., n.d. Introduction Of The Bible Using The Wonderful Wizard Of Oz. Figtree Christian. http://www.figtreechristian.org/uploads/1/2/9/0/12907370/introduction_to_the_bi ble_using_the_wonderful_wizard_of_oz.pdf

Gutierrez, L. (2014). What Does It All Mean? Scholars Study 'The Wizard Of Oz. [online] Kansas City. Available at: https://www.kansascity.com/entertainment/wizard-ofoz/article1277530.html

Hearn, M. P. (2000). The Annotated Wizard of Oz: The Wonderful Wizard of Oz. New York: Norton.

Holleran, S. (2014). Book Review: The Wonderful Wizard of Oz (1900) by L. Frank Baum. Scott Holleran. https://www.scottholleran.com/books/book-review-wonderful-wizard-oz1900-I-frank-baum/

Liebhold, P. (2016). Populism and the World Of Oz. National Museum of American History. https://americanhistory.si.edu/blog/populism-oz

Markowsky, J. (1975). Why Anthropomorphism in Children's Literature. JStore, 52(4), p.461. http://www.jstor.org/stable/41592646

Prior, K. S. (2011). Ask the Animals and they will Teach You. Flourish Magazine. http://www.flourishonline.org/2011/07/lessons-from-literature-about-animals.

Rogers, K. (2002). L. Frank Baum: Creator of Oz. 1st ed. Martin's Press.

Sax, B. (2001). The Mythical Zoo: An Encyclopaedia of Animals in World Myth, Legend, and Literature. Oxford: Harry N. Abrams.

The Wonderful Wizard Of Oz. (2020). Encyclopedia.Com. https://www.encyclopedia.com/ arts/educational-magazines/wonderful-wizard-oz\#Style 